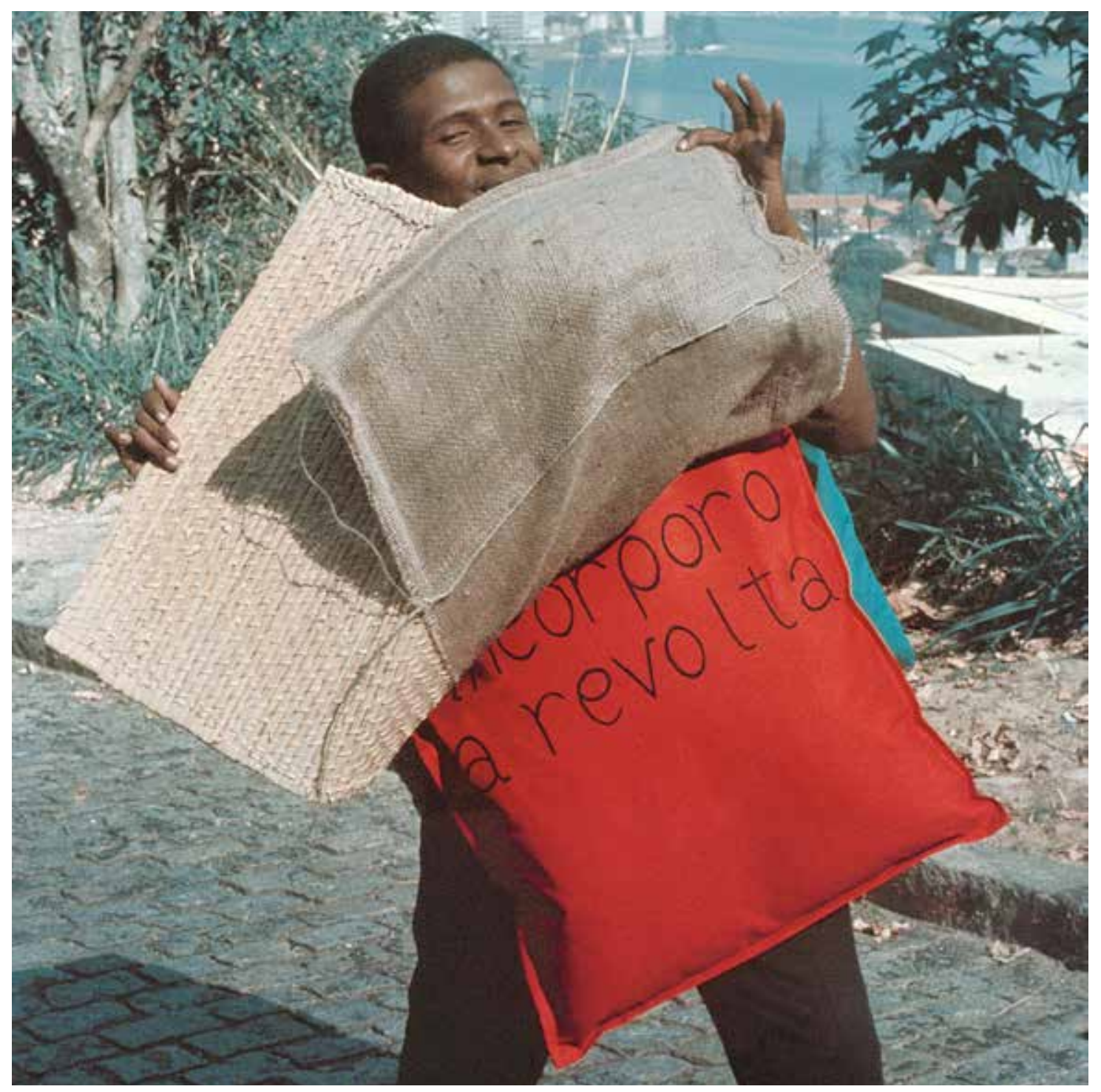


ARS Moacir dos Anjos

ano 10

n 20

\section{As ruas e as bobagens: anotações sobre o delirium ambulatorium de Hélio Oiticica*}

Palavras-chave: delirium ambulatorium; Hélio Oiticica; corpo; parangolé

keywords: delirium ambulatorium; Hélio Oiticica; body; parangolé

*O autor agradece os comentários feitos por Michael Asbury, Paula Braga, Celso Favaretto e Sérgio Bruno Martins a uma versão anterior deste ensaio, sem implicá-los, contudo, em sua versão final. Agradecimentos são também devidos ao Projeto Hélio Oiticica por disponibilizar seu arquivo para consulta.

Artigo recebido em 20 de novembro de 2012 e aprovado em 26 de novembro de 2012

Nildo da Mangueira com Parangolé P15 Capa 11 Incorporo a Revolta, 1967. Foto: Claudio Oiticica.
O artigo discute a centralidade da prática de deambular no Programa que Hélio Oiticica desenvolve a partir do início da década de 1960, embora somente ganhe maior evidência no final da década seguinte. Propõe o delirium ambulatorium como expressão mais radical do Parangolé, afirmando-o como proposta de emancipação do corpo não mais assistida por objetos e situações criados ou propostos pelo artista, mas, antes, deflagrada pelo embate direto e imediato com o mundo.

This article discusses the central role played by deambulation in the Program that Hélio Oiticica develops from the beginnings of the 1960s, even though it only captures more attention by the end of the following decade. It proposes the delirium ambulatorium as the most radical expression of Parangolé, asserting it as a proposal for emancipation of the body which is no longer assisted by objects and situations created or proposed by the artist, but rather deflagrated by the immediate and direct confrontation with the world. 
No dia 12 de novembro de 1978, Hélio Oiticica (1937-1980) MOACIR DOS ANJOS participou do evento organizado pelo artista Ivald Granato em São Paulo, intitulado Mitos vadios ${ }^{1}$. Reunindo criadores residentes do Rio de Janeiro, São Paulo e Buenos Aires, a intenção era protestar coletivamente contra a realização da I Bienal Latino-americana de São Paulo, então em curso na cidade e organizada sob o polêmico tema Mitos e magia, ficando a critério de cada um dos artistas os meios ou procedimentos a serem usados na manifestação ${ }^{2}$. No texto-release preparado para divulgar sua intervenção, e publicado no jornal Diário de São Paulo no dia 5 daquele mês, Hélio Oiticica adianta as ações que se propunha a realizar, sob o título geral de delirium ambulatorium:

“a) caminhar pela periferia da área-baldia demarcada durante a duração da performance: caminhar to and fro sem linearidade

ambulatoriar:

inventar 'coisas para

fazer' durante a caminhada

b) levar do RIO capa-faixa de murim

plastificado com cola vinílica para ser enrolada em corpos

diversos:

'procurar' a pele preta ideal para o toque da

faixa-murim:

esta capa está ainda a ser feita

c) levar em sacos

ou talvez solucionando de outro modo: talvez nos containers de vinil de fotografia apanhados em SÃO CRISTÓVÃO $\quad$ fragmentos-tokens do $\underline{\mathrm{RIO}}$

samples de asfalto da AV. PRES. VARGAS terra $>$ do MORRO DA MANGUEIRA • água da PRAIA DE IPANEMA • pequenos objetos de bazares da RUA LARGA" ${ }^{3}$

No dia do evento, contudo, a participação de Hélio Oiticica não seguiu o roteiro previsto nos itens $b$ e $c$ de seu texto-release, embora houvesse trazido consigo, do Rio de Janeiro, elementos para efetivá-los. Em vez disso, fez uma

As ruas e as bobagens:

anotações sobre o

delirium ambulatorium

de Hélio Oiticica

1. Mitos vadios estava inicialmente programado para ocorrer no dia 5 de novembro, mas teve que ser adiado uma semana por causa do mau tempo em São Paulo.

2. 0 propósito dos organizadores da I Bienal Latino-americana de São Paulo era substituir, com esse evento, a série de bienais nacionais realizadas no Brasil desde 1972 nos anos que intercalavam as edições da Bienal Internacional de São Paulo, criada em 1951. A iniciativa despertou objeções de várias ordens, seja por seu tema, seja por se sobrepor à discussão, capitaneada à época pelos críticos Aracy Amaral e Frederico Morais, de transformar a Bienal Internacional de São Paulo em uma bienal latinoamericana. Para uma discussão desse contexto geopolítico e de como o evento Mitos vadios buscou ecoar essa insatisfação, ver WHITELEGG, Isobel. Brazil, Latin America: The World. The Bienal de São Paulo as a Latin American Question. In: Third Text, v. 26, n. 1, jan. 2012, p. 131-140.

3. OITICICA, Hélio. Mitos vadios. In: OITICICA FILHO, César (Org.). Hélio Oiticica. Museu é o mundo. Rio de Janeiro: Editora Azougue, 2011, p. 177-178. 
performance nas imediações do lugar marcado para a realização de Mitos vadios, um estacionamento de automóveis na Rua Augusta, em trecho situado

\section{SALOMÃO, Waly. Quase heliogábalo. In: Waly Salomão, armarinho de miudezas. Salvador: Fundação Casa Jorge Amado, 1993, p. 139-140.}

5. Ver carta a Carla Stellweg, enviada em 4 de janeiro de 1980, em que Hélio Oiticica solicita à editora do Laica Journal que não use a ação feita por ele em Mitos vadios na edição especial da publicação sobre performance, por não considerá-la relevante. Manuscrito, documento 0034/80, acervo Projeto Hélio Oiticica.

Hélio Oiticica no evento “Mitos Vadios". São Paulo, 1978. Fotos: Solón Ribeiro.

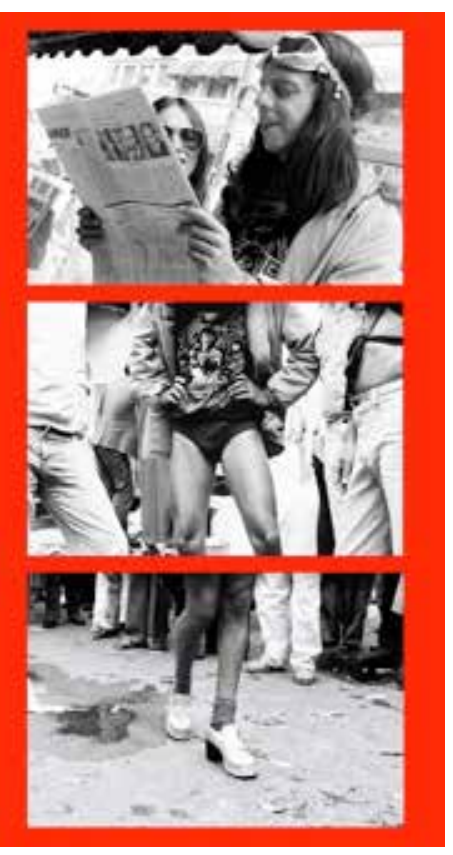

entre as ruas Oscar Freire e Estados Unidos. Mesmo que houvesse alguma parecença com o que descrevia no item $a$ do texto-release, sua ação ficou quase inteiramente circunscrita ao terreno vazio onde se concentrava o evento, pouco explorando a sua "periferia" e contrariando, assim, o que anunciara. Waly Salomão, poeta e amigo próximo do artista, dá o seu testemunho do ocorrido:

"Hélio surge demencial, imantado pela reverberação de uma aparência de bacante, dançando, girando, uma mênade enlouquecida, 'ESTOU POSSUÍDO', gargalhava das obras de arte expostas ao redor pelos outros artistas, balançava, blusa com a imagem dos Rolling Stones, blusão com a estampa do Jimi Hendrix, maquiagem carregada de ator de teatro japonês fazendo papéis femininos, o salto plataforma prateado, sério nunca, a performance era a chalaça com a pretensa seriedade dos artistas comprometidos com o mercado de arte. Insurrecto sistemático e sagaz. Frenético. Pra lá e pra cá. Rodopiava com muita naturalidade evitando sempre tornar o espaço baldio em palco"”.

Hélio Oiticica, entretanto, não parece ter ficado em nada satisfeito com sua participação em Mitos vadios. Embora houvesse pretendido fazer algo "realmente significativo" para a ocasião, algum tempo depois confessa não ter alcançado seu objetivo, considerando algumas das ações públicas e coletivas que havia realizado no passado, ou que viria a fazer em seguida, mais relevantes para o que buscava com o transbordamento de sua obra para a rua ${ }^{5}$. A despeito desse suposto fracasso, tanto a performance quanto o seu texto-release - mesmo que aparentemente pouco articulados entre si em termos de conteúdos - são importantes para compreender a sua participação em Mitos vadios como o desaguar sintético de questões desenvolvidas ao longo de muitos anos em seu Programa 6 , além de explicitar o corpo de ideias que animava o seu "estado de invenção" àquela época, estancado por sua morte súbita e prematura em março de 1980.

O que de imediato chama a atenção no texto-release que antecedeu a performance é ser apenas nessa peça, escrita em 1978, que Hélio Oiticica faz a primeira referência formal ao termo delirium ambulatorium, embora a prática de deambular estivesse no centro da vida e do trabalho do artista desde quase o princípio. De fato, em entrevista concedida no mesmo mês em que o evento Mitos vadios foi realizado, Hélio Oiticica relata que foi ainda adolescente, em inícios da década de 1950, que começou a explorar, em caminhadas, as mais diversas localidades do Rio de Janeiro, em particular as partes da cidade que escapavam às normas usuais de re- 
gulação de corpos, tais como a zona boêmia da Lapa e a região onde mais MOACIR DOS ANJOS se concentravam casas de prostituição, conhecida por Mangue ${ }^{7}$. E se, em finais da década de 1960, a expressão delirium ambulatorium já começa a aparecer em correspondências trocadas com amigos ${ }^{8}$ e a fazer parte do cotidiano partilhado com eles ${ }^{9}$, é somente em seguida à sua volta ao Rio de Janeiro, após longa temporada passada em Nova Iorque - de dezembro de 1970 a fevereiro de 1978 -, que o termo passa a ser mencionado com frequência crescente em suas anotações e cartas.

As constantes andanças pela cidade em busca por ambientes desprovidos do moralismo e do intelectualismo de seu meio de origem acabam por levar o artista a "descobrir", em começos da década de 1960 e através do amigo escultor Jackson Ribeiro, o morro da Mangueira, frequentando-o, a partir de então, com assiduidade quase diária. A despeito das fricções e conflitos com habitantes da comunidade - oriundas, em parte, das próprias diferenciações de classe que Hélio Oiticica buscava aplacar por meio de suas incursões pela "periferia" da cidade -, em algum tempo o artista se integra à escola de samba daquele bairro, torna-se habilidoso passista e desfila nos carnavais cariocas entre 1965 e 1968, ausentando-se em 1969 por estar morando em Londres e, a partir de 1970, por residir em Nova Iorque $^{10}$. É no contexto dessa vivência intensa e transformadora que Hélio Oiticica reelabora o sentido de várias das suas invenções que, em desdobrar acelerado a partir do final da década anterior, buscavam explicitar o caráter estruturante da cor na vida comum, dando-lhe concretude objetual e libertando-a do plano, como ocorre nos Bilaterais, nos Relevos espaciais e, principalmente, nos Núcleos, nos Penetráveis e nos Bólides. E o ponto crucial para esta ressignificação do que havia feito até então é a invenção do Parangolé, em 1964.

Inicialmente, o termo Parangolé designava apenas o conjunto de "Estandartes", “Tenda” e, principalmente, "Capas" feitos com tecido e outros materiais encontrados no cotidiano ordinário, os quais deveriam ser carregados ou vestidos em situações diversas de movimento corporal para existirem como trabalhos. $O$ corpo não serviria aqui, porém, como mero suporte animado das peças: tratava-se de promover a "incorporação do corpo na obra e da obra no corpo" ${ }^{11}$, de modo que aquele que era antes mero espectador de uma criação artística se tornava, por um processo de "in-corporação" do trabalho, participante ativo e indissociável dele. Fundamental para esse entendimento foi a descoberta da dança (por meio da presença do samba na Mangueira) como elemento descondicionador de

As ruas e as bobagens: anotações sobre o delirium ambulatorium de Hélio Oiticica

6. "[T]odo projeto que eu faço gradativamente vai entrando numa coisa que eu chamo de Programa, na realidade são Programas não programados, eu chamo de Programs in progress, na realidade tudo se transforma num programa a longo prazo, todas as coisas que eu faço são coisas paulatinas e a longo prazo, por isso não tem sentido dizer que há uma repetição (...)." OITICICA, Hélio. Depoimento de Hélio Oiticica para Ivan Cardoso, janeiro de 1979. In: OITICICA FILHO, César; COHN, Sérgio; VIEIRA, Ingrid (Org.). Hélio Oiticica. Coleção Encontros. Rio de Janeiro: Editora Azougue, 2009, p. 238.

7. OITICICA, Hélio. Um mito vadio (depoimento a Jari Cardoso). In: OITICICA FILHO, César; COHN, Sérgio; VIEIRA, Ingrid (Org.). Op. cit., p. 214.

8. Carta de Hélio Oiticica para Lygia Clark datada de 2 de agosto de 1978. In: FIGUEIREDO, Luciano (Org.). Lygia Clark Hélio Oiticica. Cartas 1964 - 1974. Rio de Janeiro: Editora UFRJ, 1996, p. 161.

9. “Hélio e eu saíamos muito para andar de madrugada pela cidade. Ele me dizia: vamos curtir. 0 delírio ambulatório era isso: você saía pela cidade toda, que não tinha perigo nenhum,e 
códigos reguladores inscritos nos corpos e como contraponto à "excessiva intelectualização" dos procedimentos artísticos ${ }^{12}$.

ia descobrindo as coisas, vendo e vivendo."

PAPE, Lygia. Lygia por Lygia. In: MATTAR,

Denise (Org.). Lygia

Pape. Intrinsecamente anarquista. Rio de Janeiro: Relume Dumará, 2003, p. 75.

10. A existência de recorrentes conflitos entre Hélio Oiticica e os moradores da Mangueira, contrariando a ideia de uma integração sem aparas presente em vários comentadores da obra do artista, é apontada por ASBURY, Michael. 0 Hélio não tinha ginga. In: BRAGA, Paula (Org.).

Fios soltos: a arte de Hélio Oiticica. São Paulo: Perspectiva, 2008, p. 30.

11. Depoimento de Hélio Oiticica para Ivan Cardoso, janeiro de 1979. In: OITICICA FILHO, César; COHN, Sérgio; VIEIRA, Ingrid (Org.). Op. cit., p. 229.

12. OITICICA, Hélio. Anotações sobre o parangolé. In: OITICICA FILHO, César (org.). Op. cit., p. 75.

13. "Para mim, a característica mais completa de todo esse conceito da ambientação foi a formulação do que

Tropicália, Penetráveis PN2 e PN3, 1967. Foto: César Oiticica Filho.
Por meio do uso das capas-Parangolés, o samba dançado nos morros foi inscrito no campo artístico, subvertendo, de maneira inédita, separações arbitrárias entre diferentes formas de arte e também hierarquias entre o que se supunha ser alta e baixa culturas. Mais importante ainda, o Parangolé desmanchava os limites entre aquilo que é proposto como ato criativo e a emergência de significados para tal gesto por meio da participação ativa do "outro", borrando distinções estanques entre artista e espectador. Diante dessa constatação, Hélio Oiticica ressaltou, em reflexões que fez a respeito do assunto, o fato de o Parangolé não ser somente um termo que identificava um conjunto de trabalhos que partilhavam certos atributos, mas, principalmente, um conceito que revelava os limites do entendimento convencional de arte, no qual algo é criado apenas para a "contemplação" alheia. Como corolário dessa posição, passa a sugerir que o lugar de efetivação desses trabalhos não poderia ser mais a "exposição", propondo, em seu lugar, a noção de "ambiente"13.

Nos "ambientes" - espaços estruturados para a participação -, o artista (agora, "motivador") lançaria mão de todas suas possibilidades e estratégias criativas e as ofereceria à invenção livre do espectador (agora, "participador"), concedendo à arte "ambiental" um caráter cambiante e instável, em que o ato de criar não se distingue da proposição de uma atitude criadora para o outro ${ }^{14}$. Embora, retrospectivamente, Hélio Oiticica identificasse características de

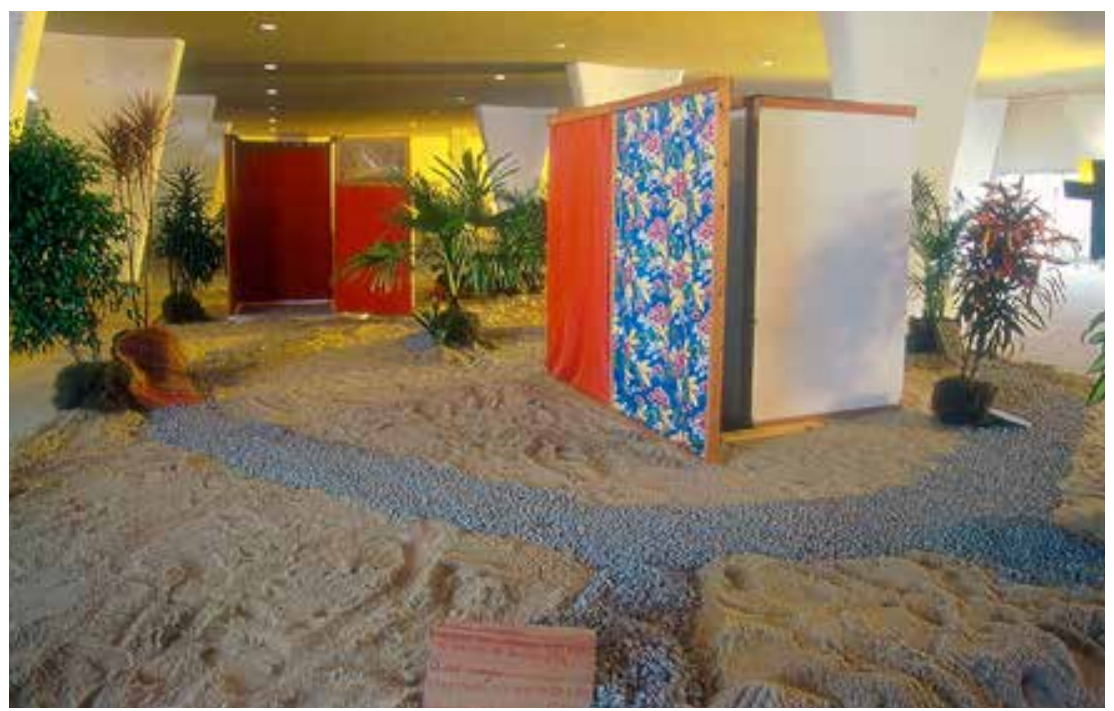


uma arte ambiental já nos Núcleos, Penetróveis e Bólides, vários destes seriam,

MOACIR DOS ANJOS a partir da invenção do Parangolé, retomados e reinseridos em ambientes que o artista iria construir nos anos seguintes, sendo o primeiro deles aquele a que chamou de Tropicália (1967), em que deu "ambientação" a dois Penetráveis anteriormente realizados.

Em nenhum outro momento o Programa de Hélio Oiticica esteve mais diretamente informado por sua vivência nos morros do Rio de Janeiro - e, em particular, na comunidade da Mangueira - do que em Tropicália, estabelecendo essa imersão como vórtice do processo de reinvenção do ato criativo que pretendia inaugurar com seu "programa ambiental". A experiência de andar pelas "quebradas" de favelas, esgueirando-se por entre barracos e becos, era emulada, nesse ambiente, por meio da presença de Penetráveis feitos de passagens estreitas e articulados por caminhos de areia ou brita. As casas improvisadas que havia nos bairros pobres que frequentava - respostas originais a uma situação de falta e atestado das desigualdades de acesso a moradias - eram invocadas, ademais, nos arranjos construtivos que davam forma aos Penetráveis ali ambientados e reunidos $^{15}$. Embora existissem, desde o início da década, como peças separadas e autônomas, esses Penetráveis eram ali rearrumados de modo orgânico pelo artista. Articulados por meio de elementos da natureza (além da areia e brita, folhagens e araras vivas) e da cultura locais, integravam agora um ambiente capaz de oferecer, àqueles que o percorressem descalços, a sensação de estar "pisando a terra", evocando e partilhando o que, segundo o depoimento de Hélio Oiticica, ele mesmo sentia ao caminhar por entre as vielas dos morros e favelas cariocas ${ }^{16}$.

Tudo somado, havia em Tropicália a vontade de propor, em contraposição à "avalanche informativa e imagética" que a sociedade moderna impunha desde fora, um retorno a experiências basilares de vida, uma estratégia para descondicionar-se de um contexto social alienante. Em seu conjunto, os elementos presentes no ambiente buscavam recuperar uma sensação vivida e apresentá-la simbolicamente ao outro, processo que correspondia, segundo Hélio Oiticica, à elaboração de um "mapa" imaginado da cidade do Rio de Janeiro, o qual condensava imagens e lugares reais por ele conhecidos ${ }^{17}$. Anos depois, o artista viria a identificar esses procedimentos condensados em Tropicália com um processo de "mitificação" consciente do cotidiano ${ }^{18}$. Mitificação que não se confundia, entretanto, com mera celebração do primitivo ou do precário, expondo, por meio da construção de uma imagem fragmentada de brasilidade, atritos e incoerências da vida do país ${ }^{19}$.
As ruas e as bobagens: anotações sobre o delirium ambulatorium de Hélio Oiticica

chamei Parangolé. É isto muito mais do que um termo para definir uma série de obras características: as capas, estandartes e tenda; Parangolé é a formulação definitiva do que seja antiarte ambiental, justamente porque nessas obras foi-me dada a oportunidade, a ideia, de fundir cor, estruturas, sentido poético, dança, palavra, fotografia - foi o compromisso definitivo com o que defino por totalidade-obra, se é que de compromissos se possam falar nessas Ibidem, p. 82.

14. Idem, Ibidem, p. 81.

15. Para uma discussão extensa sobre a relação entre os modos construtivos empregados nas favelas e a obra de Hélio Oiticica, ver JACQUES, Paola Berenstein. Estética da ginga. A arquitetura das favelas através da obra de Hélio Oiticica. Rio de Janeiro: Editora Casa da Palavra/RIOARTE, 2001.

16. "Quando eu ando ou proponho que as pessoas andem dentro de um Penetrável com areia e pedrinhas... eu estou sintetizando a minha experiência da descoberta da rua através do andar... do espaço urbano através do detalhe, do andar... do detalhe síntese do considerações." Idem, 
Os desdobramentos do Programa de Hélio Oiticica que se segui-

ano 10

andar..." Depoimento de Hélio Oiticica para Ivan Cardoso, janeiro de 1979. In: OITICICA FILHO, César;

COHN, Sérgio; VIEIRA, Ingrid (Org.). Op. cit., p. 231.

17. Entrevista a Guy Brett. Londres, fevereiro de 1969. In: OITICICA FILHO, César; COHN, Sérgio; VIEIRA, Ingrid (Org.). Op. cit., 2009. p. 60.

18. OITICICA, Hélio. Anotações sobre o parangolé. In: OITICICA FILHO, César (org.). Op. cit., p. 75.

19. Para uma discussão sobe o processo de construção de uma “imagem" de Brasil em Tropicália, ver MARTINS,

Sérgio Bruno. Hélio Oiticica. Mapping the constructive. In: Third

Text, v. 24, n. 4 , jul. 2010, p. 409-422. Conforme $o$ autor sugere,

"The images in Tropicália are stereotypical icons of 'brazilianness', but paradoxically presented ones: an accumulation of 'Brazilian' images that fail to cohere into a smooth sense of identity. The viewer is now drawn into making a whole array of supposedly familiar images into a nonsense. (...) What [Hélio Oiticica] terms the 'objectivation' of a Brazilian image relates to a process of image and myth-making - that is 'experimentally' enacted by Tropicália". ram à Tropicália apontam para o reconhecimento de um forte elemento autorreferencial nesse ambiente e para a simultânea vontade do artista de destituir sua produção de tal característica, dessa maneira atenuando a mitificação de sua vivência urbana. $\mathrm{O}$ amadurecimento dessa mudança de posição face à obra levou à elaboração, ainda em 1967, do conceito de Suprassensorial, em que o artista abranda, no âmbito de seu programa, a importância da "estruturação" de um ambiente dado, passando a privilegiar os "comportamentos" que suas proposições poderiam ativar naqueles que viessem a interagir com elas. O Suprassensorial seria "a tentativa de criar, por proposições cada vez mais abertas, exercícios criativos (...) dirigidos aos sentidos, para através deles, da 'percepção total', levar o indivíduo a uma 'suprassensação', ao dilatamento de suas capacidades sensoriais habituais, para a descoberta do seu centro criativo interior, da sua espontaneidade expressiva adormecida, condicionada ao cotidiano"20.

O conceito do Suprassensorial esteve no centro do evento Apocalipopótese (1968), realizado ao ar livre, no Rio de Janeiro. Por meio de convites feitos a outros artistas, aproximou uma série de propostas destinadas a ativar uma experiência coletiva e casual de criação, aberta aos estímulos sensoriais oferecidos pelas circunstâncias daquele lugar e momento, sem que houvesse fim certo e tampouco finalidade definida, de modo que o "verdadeiro fazer" fosse a "vivência do indivíduo" 21 . Entre as propostas apresentadas estavam as Urnas Quentes, de António Manuel, o Ovo, de Lygia Pape, uma demonstração com cães amestrados, organizada por Rogério Duarte, e um conjunto de Parangolés, usados por Hélio Oiticica e um grupo de amigos da Mangueira. Propostas que não eram consideradas - individualmente ou em conjunto - trabalhos com significados estanques, cada uma delas sendo tão somente uma "proposição para o comportamento". Propostas que operariam, nesse contexto, como "células germinativas" a partir das quais subjetividades se manifestariam e se formariam livremente como ação ou pensamento, constituindo situações até então inexistentes ${ }^{22}$. Em vez de oferecer um mapa pessoal para servir de baliza aos percursos investigativos de outros, como fizera em Tropicália, Hélio Oiticica passava agora a investir na construção de estruturas moldáveis ao comportamento alheio, propiciando a qualquer um o "exercício experimental da liberdade"23 e a invenção de cartografias particulares.

Também o Éden (1969) - projeto ambiental desenvolvido na galeria Whitechapel, em Londres, em que Hélio Oiticica articulou e ressignificou 
parte relevante de sua produção até então - teve no Suprassensorial um conceito organizador, posto que buscava traduzir "experiências pessoais em algo aberto" ${ }^{24}$, disponibilizando-as para a interação inventiva do outro. Conforme compara Celso Favaretto, "enquanto em Tropicália o participante fazia de sua caminhada um exercício com as imagens, no Éden não há nada a ser decifrado; entrando num campo de ações desconhecidas, que despertam os sentidos e ativam a imaginação, ele é levado a produzir novas relações entre elementos (objetos, materiais), as sensações e as ideias"25. Nesse sentido, o rápido desenrolar do seu programa da Tropicália até o Éden pode ser entendido como um processo de "desmitificação" do cotidiano e da vida das ruas do Rio de Janeiro, ainda que, neste momento, Hélio Oiticica não o tenha formulado dessa maneira.

Em várias das proposições contidas no ambiente Éden, é igualmente patente o papel desempenhado pelo conceito de Crelazer, elaborado quase em simultâneo ao de Suprassensorial. Por meio desse neologismo que ata as noções de criação e lazer, Hélio Oiticica sugeria que a participação inventiva poderia abarcar também os estados de repouso, invocados como "estados vivos" capazes de catalisar "energias não-opressivas" em suas proposições, e não mais como momentos de mera dispersão, subvertendo assim o que rezava o senso comum sobre situações em que não há trabalho ativo $^{26}$. A ideia de Crelazer está presente em “células germinativas” diversas do Éden: cabines, penetráveis, tendas e, especialmente, em espaços para habitar o que chamou de $\operatorname{Ninhos}^{27}$, os quais ficavam à disposição de todos

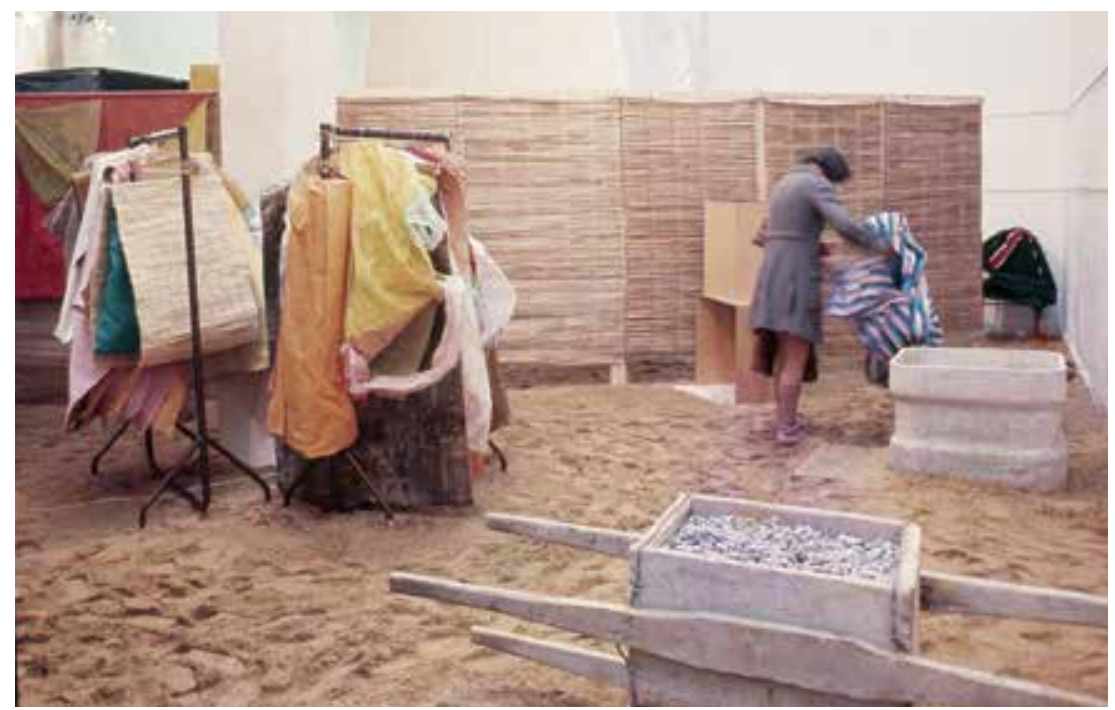

MOACIR DOS ANJOS

As ruas e as bobagens: anotações sobre o delirium ambulatorium de Hélio Oiticica

20. OITICICA, Hélio. 0 aparecimento do suprassensorial na arte brasileira. In: OITICICA FILHO, César (Org.). Op. cit., p. 106.

21. Idem.

22. OITICICA, Hélio. A obra, seu caráter objetual, o comportamento. In: OITICICA FILHO, César (Org.). Op. cit., p. 139-141.

23. A expressão "exercício experimental da liberdade" foi empregada diversas vezes pelo crítico Mario Pedrosa na análise dos trabalhos de Hélio Oiticica e Lygia Clark como modo de acentuar o que considerava mais relevante em suas obras, para além de suas concreções diversas.

24. Idem, Ibidem.

25. FAVARETTO, Celso. A invenção de Hélio Oiticica. São Paulo: Edusp, 1992, p. 188.

26. OITICICA, Hélio. Crelazer e As possibilidades do Crelazer. In:FIGUEIREDO, Luciano; PAPE, Lygia; SALOMÃO, Waly (Org.). Aspiro ao Grande Labirinto. Seleção de textos (19541969). Rio de Janeiro: Rocco, 1986. p. 113-117.

Vista da exposição "Whitechapel experience", na Whitechapel Gallery, Londres, 1969. Foto de autor desconhecido. 
para o "lazer-fazer não interessado"28. O artista nunca chegou a realizar, contudo, o projeto Barracão, destinado ao Rio de Janeiro e que seria, conforme anunciou, "ambiente total comunitário do Crelazer"29.

27. Os Ninhos foram ainda apresentados por Hélio Oiticica em situações distintas e de maneiras variadas: numa residência artística na Universidade de Essex; na mostra Information, no MoMA, em Nova lorque; e, por fim, no seu apartamento na cidade americana, quando para lá se muda em 1970.

28. OITICICA, Hélio. Crelazer e As possibilidades do Crelazer. In: FIGUEIREDO, Luciano; PAPE, Lygia; SALOMÃO,

Waly (Org.). Op. cit., p. 113-117.

29. Idem, Ibidem, p. 117.

30. Para uma apresentação e discussão detalhada do desdobrar do Programa de Hélio Oiticica, ver FAVARETTO,

Celso. Op. cit. Ver também, principalmente sobre a primeira década da trajetória do artista, COCCHIARALE, Fernando.

Da contemplação ao

suprassensorial. In:

Hélio Oiticica. Museu é o mundo. [Catálogo da exposição]. São Paulo: Itaú Cultural, 2010, p. 26-66.

Bólide B55 Bólide Área 2, 1967, dentro da obra ambiental Éden, na exposição "Whitechapel experience", na Whitechapel Gallery, Londres, 1969. Foto de autor desconhecido.
Embora apenas esboçada aqui, a trajetória percorrida por Hélio Oiticica ao longo da década de 1960 ressalta a articulação orgânica entre as distintas criações que formavam o seu Programa. E o elemento fundamental nesse processo de aproximação e cruzamento entre trabalhos foi o conceito de Parangolé, o qual ancora o descondicionamento do corpo e a convocação do outro para ingressar em um "estado de invenção" ${ }^{30}$. Esse processo de desmanche de fronteiras não se estanca, todavia, no território simbólico por ele criado. Estendendo o sentido de ambiente para além do que um recinto qualquer demarca, o artista propunha, no limite, apropriar-se de coisas que estão em qualquer lugar - seja no seu apartamento ou nas ruas - e convocar quem estiver disposto a interagir criativamente com elas, confundindo experiência cotidiana e prática artística: "Museu é o mundo", afirmava sem hesitação ${ }^{31}$.

A partir do início da década de 1970, e ao longo dos mais de sete anos passados em Nova Iorque, Hélio Oiticica desenvolveu uma série de projetos para a construção de grandes e labirínticos Penetráveis, pensados para áreas públicas e reunidos sob o nome de Subterranean Tropicália Projects, os quais jamais foram executados. Transformou o próprio apartamento, contudo, em um espaço feito de muitos Ninhos (Babylonests), nos

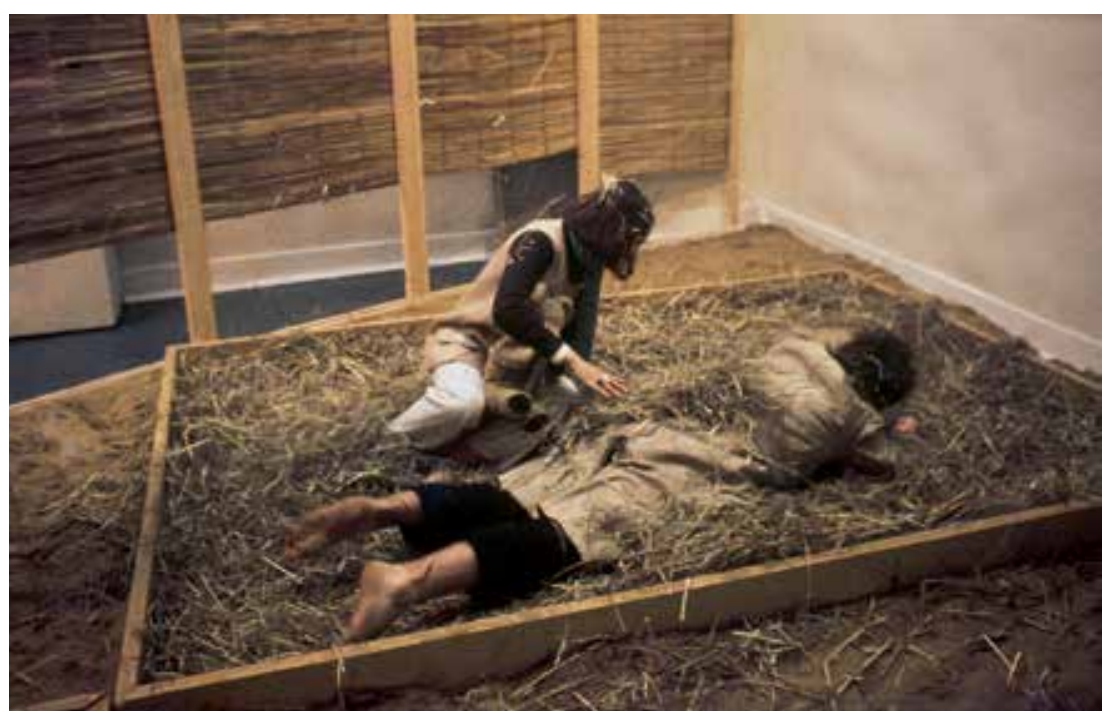


quais vivia, trabalhava e recebia, por durações diversas, amigos que moraMOACIR DOS ANJOS vam na cidade norte-americana ou passavam por ela, instaurando nele um "dia a dia experimentalizado" ${ }^{2}$. Ainda que em escala doméstica, formula de novo, e com renovada intensidade, questões relativas a um viver criativo, aberto e partilhado, já presentes nos conceitos de Suprassensorial, Crelazer e Barracão ${ }^{33}$.

Densa em reflexões textuais sobre seu Programa e em experimentos com as linguagens escrita e audiovisual, a temporada nova-iorquina também reaviva, em novo contexto, a paixão deambulatória do artista. Fascinado pelo longo e complexo poema Guesa ("errante" ou "sem lar", na explicação de Augusto e Haroldo de Campos) $)^{34}$, do escritor maranhense Sousândrade (1833-1902), e, em particular, pelo canto intitulado "O Inferno de Wall Street", Hélio Oiticica busca identificar, na Nova Iorque em que vivia, os lugares descritos no texto escrito um século antes ${ }^{35}$. A localização geográfica das cenas criadas pelo poeta seria explorada no filme (super-8) Agripina é Roma-Manhattan (1972), cujo roteiro era recheado de episódios "sousandradinos"36, um deles contando com as participações do artista brasileiro Antonio Dias e do ator porto-riquenho Mário Montez. O filme, porém, permaneceu inacabado.

Quase ao término do período em que viveu em Nova Iorque, Hélio Oiticica cria uma nova série de projetos e maquetes para construções destinadas a espaços públicos. Concebidos como edificações a serem apropriadas pela população em seu cotidiano comum, as Magic Squares filiam-se, de modo imediato, à vontade construtiva que guiou a concepção dos Subterranean Tropicália Projects e também, mais remotamente no tempo, a projetos de penetráveis concebidos no início da década de 1960, como o Projeto Cães de Caça (1961). Feitos de planos de cor luminosos que formam ambientes para serem percorridos e vivenciados, somente duas décadas após sua concepção (postumamente, portanto) um desses projetos, a Magic Square No. 5, foi executado: uma primeira versão no Museu do Açude, na cidade do Rio de Janeiro, e uma segunda vez em Inhotim, em Brumadinho, Minas Gerais. Posteriormente, mais um desses projetos, a Magic Square No. 3, também foi construído, desta feita em uma coleção privada instalada no interior do estado do Rio de Janeiro ${ }^{37}$. É curioso que nenhum deles tenha sido realizado em espaços urbanos e sem a regulação explícita de instituições públicas ou privadas de arte acerca de seu uso, o que parece atraiçoar, em certa medida, a vocação de tais trabalhos para descondicionar os modos de vida no dia a dia, seja pela instauração de

As ruas e as bobagens: anotações sobre o delirium ambulatorium de Hélio Oiticica

31. OITICICA, Hélio. Anotações sobre o parangolé. In: OITICICA FILHO, César (Org.). Op. cit., p. 82.

32. OITICICA, Hélio. MUNDO-ABRIGO. Texto datilografado datado de 27 de outubro de 1973. Documento 0194/73, acervo Projeto Hélio Oiticica.

33. A estrutura celular dos Ninhos aparece também no Newyorkaises, projeto de livro nunca realizado que reuniria toda a produção de Hélio Oiticica em Nova lorque, incluindo nove Cosmococas, as cinco primeiras das quais feitas em parceria com Neville D'Almeida, e que somente começariam a ser executadas na década de 2000. Ver BRAGA,

Paula. Quantas vidas tem a arte? In: Hélio Oiticica.

Museu é o Mundo.

[Catálogo da exposição]. São Paulo: Itaú Cultural, 2010, p. 118-126.

34. CAMPO, Augusto de; CAMPOS, Haroldo de. ReVisão de Sousândrade. Rio de Janeiro: Nova Fronteira, 1982, p. 40. Apud BRAGA, Paula. Hélio Oiticica: simultaneidade, consequência e retorno, $p$. 15. [Texto não publicado.]

35. AGUILAR, Gonzalo. $\mathrm{Na}$ selva branca: o diálogo velado entre Hélio Oiticica e Augusto e Haroldo de Campos. In: BRAGA, 
uma temporalidade distinta daquela marcada pela rotina de trabalho, seja pela ativação de comportamentos diversos daqueles já normatizados.

Paula (Org.). Fios soltos: a arte de Hélio Oiticica. São Paulo: Perspectiva, 2008, p. 240-241. Para fazer essa identificação, Hélio Oiticica teria contado com a ajuda de um estudo sobre a história de Nova lorque feito por sua amiga e historiadora de arte Dore Ashton. ASBURY, Michael. Hélio Oiticica: o q faço é música. [Texto não publicado.]

36. LEORK (para CARLOS VERGARA). Carta datada de 22 de julho de 1972.

Documento 0212/72, acervo Projeto Hélio Oiticica.

37. BRAGA, Paula. Quantas vidas tem a arte? In: Hélio Oiticica. Museu é o mundo. [Catálogo da exposição]. São Paulo: Itaú Cultural, 2010. p.127.

38. “(...) tudo o q veio antes desse processo de desmitificação não passa de PRELÚDIO àquilo q há de vir e q já começa a surgir a partir desse ano na minha 'obra': ao q antes chamei de OVO há de seguir o NOVO - e já era sem tempo!" OITICICA, Hélio. Texto sobre o objeto na arte brasileira, feito a pedido de Daisy Peccinini.

Documento 0101/77,

Invenção da Cor, Penetrável Magic Square n 5 The Luxe, 1978. Inhotim, 2007.

Foto: César Oiticica Filho.
A despeito das filiações apontadas e do amortecido impacto dos projetos realizados, as Magic Squares conectam-se também, ainda que de modo menos claro, à ideia de um delirium ambulatorium, formalmente elaborada em finais da década de 1970, pouco após o retorno definitivo do artista ao Rio de Janeiro. Embora diferentes em quase quaisquer aspectos, há nas duas propostas - principais vetores de sua atuação no período - a mesma afirmação de contiguidade entre o gesto criador e o ato vivido, expressa na incorporação ou dissolução do cotidiano e do que ocorre nas ruas no outrora limitado campo consagrado à arte. Magic Squares e delirium ambulatorium são não somente partes constituintes de um mesmo programa ambiental conceituado desde meados da década de 1960, mas desdobramentos do que teria sido apenas, até então, o "prelúdio" de sua obra ${ }^{38}$.

A reafirmação, a partir de 1978, da centralidade da vivência nas ruas no Programa de Hélio Oiticica é acompanhada, todavia, de uma reavaliação do momento-chave que, na década de 1960, fez o seu trabalho transbordar para fora dos limites estreitos das convenções artísticas vigentes e gradualmente voltar-se para o espaço de convívio público. O artista reconhece, agora de maneira explícita, que, ao contrário da mitificação de sua vivência tal como incorporada em proposições passadas (e, em particular, em Tropicália), o seu reencontro com o Rio de Janeiro se dá como um processo de "desmitificação", em que todos os seus cantos e pedaços

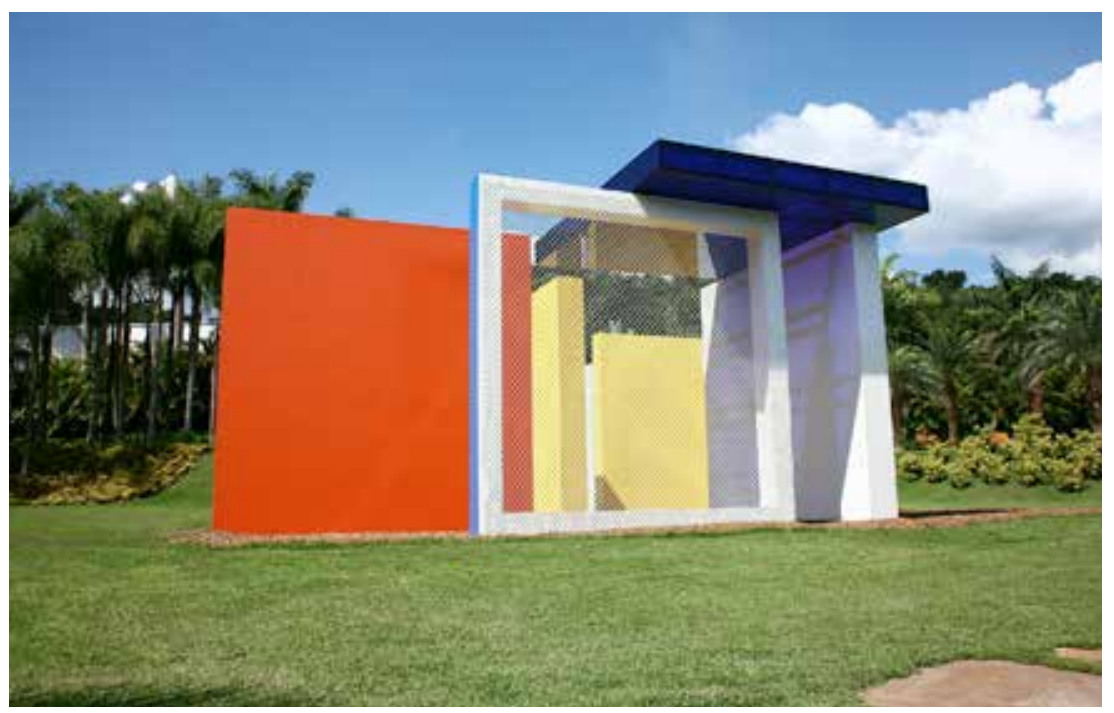


- a pedra do Pão de Açúcar, a estação Central do Brasil, as ruas do centro,

MOACIR DOS ANJOS

As ruas e as bobagens: anotações sobre o delirium ambulatorium de Hélio Oiticica

acervo Projeto Hélio Oiticica. Ver também, em sentido semelhante, OITICICA, Hélio. Hélio está de volta. Entrevista concedida a Cleusa Maria e publicada originalment no Jornal do Brasil em 8 de março de 1978. In: OITICICA FILHO, César; COHN, Sérgio; VIEIRA, Ingrid (Org.). Op. cit., p. 169.

39. "Para mim, primeiro o Rio era um mito, eu tinha mistificado ele de tal maneira que eu tive de sair dele e passar esses anos todos fora, para descobrir que depois do processo de mistificação vem o de desmitificação... (não confundir desmitificação com desmistificação, apesar do segundo ser parte do primeiro). Aí eu descobri que o processo de mistificação é muito importante, mas ele tem que vir acompanhado com o de desmitificação." Depoimento de Hélio Oiticica para Ivan Cardoso, janeiro de 1979. In: OITICICA FILHO, César; COHN, Sérgio; VIEIRA, Ingrid (Org.). Op. cit., p. 230.

40. CERTEAU, Michel de. A invenção do cotidiano. v. 1: Artes de Fazer. São Paulo: Editora Vozes, 2008, p. 179.

41. Idem, Ibidem, p. 181.

42. Embora o termo "deriva" esteja fortemente associado às reflexões sobre as práticas 
mento de fragmentos-tokens ao longo do delirium ambulatorium de Hélio Oiticica dá ainda mais concretude a essas analogias, articulando-as como

deambulatórias da Internacional Situacionista na década de 1950, não há quaisquer evidências de que Hélio Oiticica tenha sido em alguma medida influenciado por elas ou mesmo que conhecesse os textos de Guy Debord sobre o assunto. Conforme se depreende de carta enviada a Mário Pedrosa,

é somente em inícios da década de 1970 que Hélio Oiticica tem contato com as ideias do escritor francês, através de uma "edição underground" de La Societé du Spectacle editada nos Estados Unidos, onde então já residia. Nesse livro, porém, o foco de Guy Debord é completamente outro, e o que chama a atenção do artista brasileiro é a análise nele feita sobre a alienação do espectador nas sociedades contemporâneas, pertinente para a compreensão do que havia feito no Éden. Carta a Mário Pedrosa, em 30 de julho de 1971. Documento 0920/71, acervo Projeto Hélio Oiticica.

43. FIGUEIREDO, Luciano. The World is a Museum: Appropriation and Transformation in the Work of Hélio Oiticica. In: RAMÍREZ, Mari Carmen (Org.). Hélio Oiticica. The Body of Colour. Londres/ Houston: Tate Publishing/ The Museum of Fine Arts, 2007, p. 123. elementos de uma retórica da deriva ${ }^{42}$. Afinal, se fragmentos materiais do Rio de Janeiro substituem simbolicamente a totalidade da cidade, também expõem ausências e vazios que dão lugar à invenção do caminhante.

Alguns resultados desse permanente reconhecimento "mítico-concreto" da cidade são mais conhecidos que outros por terem sido fotografados e assim publicados ou exibidos. Entre estes, estão fragmentos-tokens semelhantes aos propostos para o evento Mitos vadios (item $c$ do texto-release) e somente realizados um pouco depois: tomando três recipientes plásticos idênticos e vazios achados ao acaso no Bairro de São Cristóvão, o artista inseriu neles, respectivamente, fragmentos de asfalto da Avenida Presidente Vargas, um punhado de terra retirado do Morro da Mangueira e um pouco de água do mar coletada na praia de Ipanema. Um quarto recipiente permaneceu vazio ou, talvez seja possível dizer, cheio do ar da cidade ${ }^{43}$.

O fragmento-token mais divulgado em publicações e relatos é, contudo, um pedaço de asfalto, recolhido entre os escombros das obras do metrô na Avenida Presidente Vargas e nomeado de Manhattan Brutalista (1978) por lembrar, ainda que toscamente, o desenho cartográfico da região nova-iorquina. Ao aludir, simultaneamente, a partes das duas cidades em que por mais tempo viveu (os contornos do mapa de Manhattan recortados em matéria pertencente ao chão do centro do Rio de Janeiro), Hélio Oiticica faz sugestiva junção delas, como se revisitasse sua cidade natal à luz da vivência na região de Nova Iorque. Esse escombro, segundo o artista, teria sido "apropriado como um objet-semimágico-trouvé e resulta de uma experiência do mito-desmitificado" ${ }^{4}$. Junto a pedaços de calçada da mesma avenida carioca compostos de mosaico de pedras e cimento, aquele fragmento de asfalto foi instalado no banheiro do seu estúdio no Rio de Janeiro, todos fazendo parte de um "jardim transformável", intitulado Av. Presidente Vargas - Kyoto/Gaudi (1978), nome que é homenagem a "lugares míticos" pelos quais tinha interesse: os jardins da cidade japonesa e as construções feitas de fragmentos de cerâmica e pedra projetadas pelo arquiteto catalão ${ }^{45}$.

Um ano depois dessa experiência, Hélio Oiticica confirmava a sua importância como momento de gestação de algo novo no seu trabalho ${ }^{46}$. De fato, é a ideia de delirium ambulatorium e o que resultou de suas expedições à Avenida Presidente Vargas que dão origem à formulação do programa in progress CAJU, com o qual o artista iria se ocupar ao longo de muitos meses em $1979^{47}$. Para esse projeto, Hélio Oiticica propunha 


\section{MOACIR DOS ANJOS}

As ruas e as bobagens: anotações sobre 0 delirium ambulatorium de Hélio Oiticica

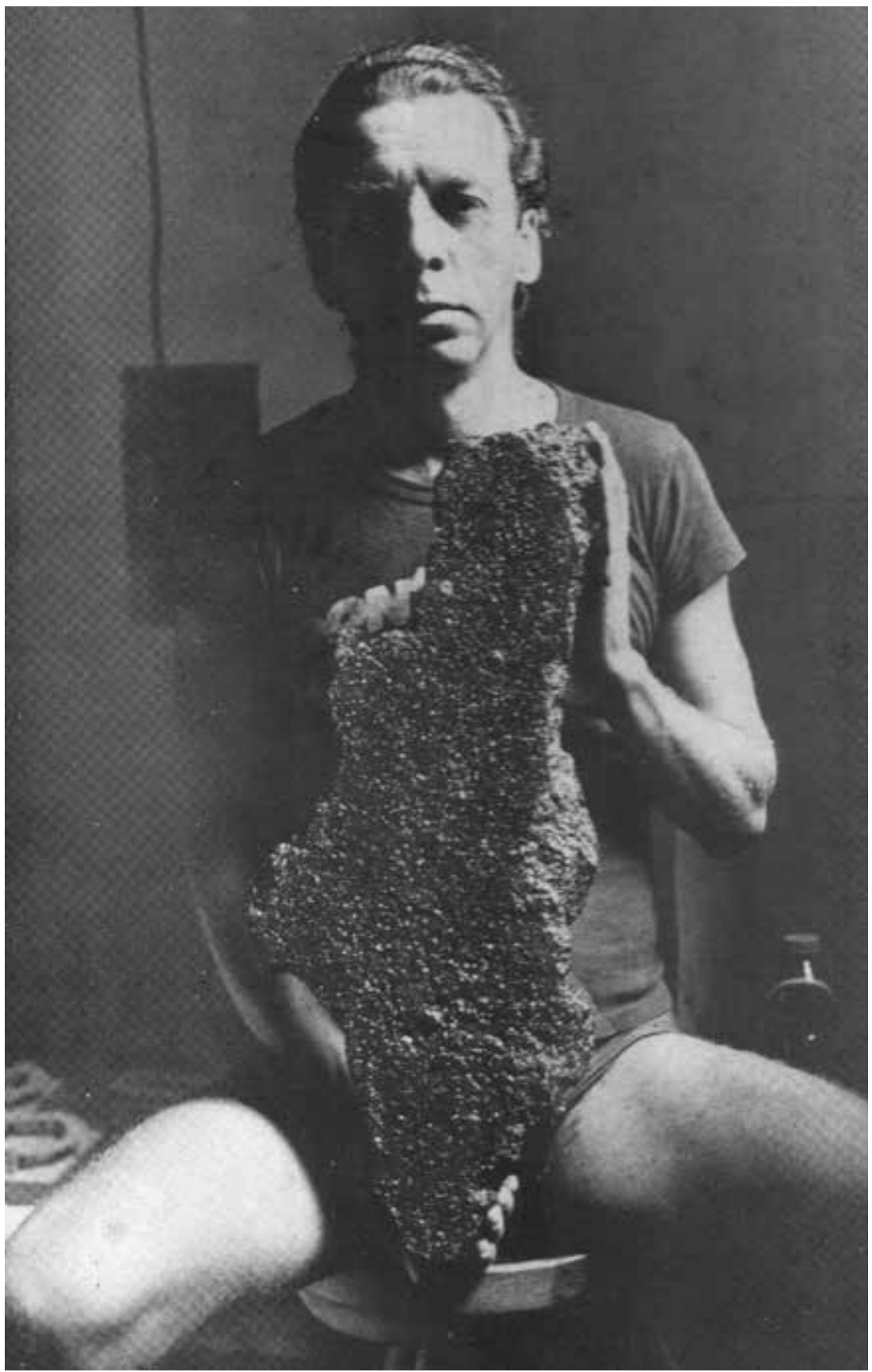

44. Depoimento de HO para Nelson Mota, 21.09.78 (manuscrito). Parcialmente publicado em HÉLIO brutaliza

Manhattan, via Kyoto e Gaudi. 0 Globo, 26 set.

1978.

45. Idem, Ibidem

46. Carta a Carla Stellweg, editora do Laica Journal, em 3 de outubro de 1979:

"I think that starts a new

thing in my work...".

Manuscrito, documento 0028/79, acervo Projeto Hélio Oiticica.

47. Relatórios de visita ao Caju $-1^{\circ}$. Acontecimento Poético Urbano: Kleemania. 29.01.1979. Manuscrito, documento 0123/78, acervo Projeto Hélio Oiticica.

Hélio Oiticica com a obra Manhattan Brutalista, objeto semi-mágico trouvée, 1978.

Foto: Roberto Wolfenson. 
ARS

ano 10

n 20

Av. Presidente Vargas Kyoto/Gaudi, 1978.

Ateliê do artista na Rua Ataulfo de Paiva, Leblon, Rio de Janeiro. Foto de autor desconhecido.

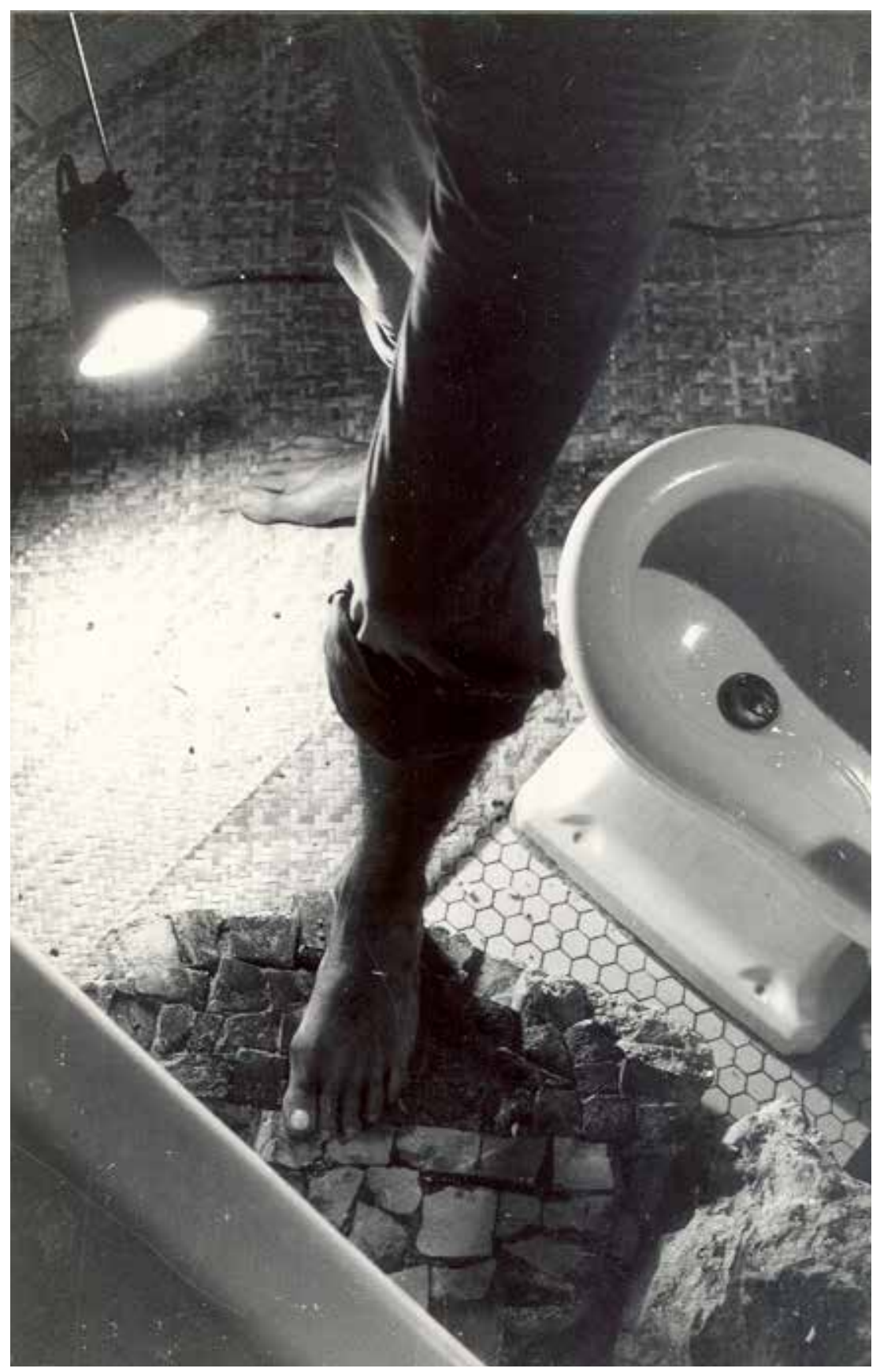


convidar diversos "participadores" (incluindo artistas, críticos, designers, MOACIR DOS ANJOS poetas, fotógrafos, cineastas, paisagistas), além de outros que quisessem aderir espontaneamente à proposta, para tomar o então depreciado bairro do Caju (região que fora importante durante o período imperial Português no Brasil) como se este fosse um playground, em que os visitantes poderiam realizar trabalhos antes esboçados e/ou tentar descobrir ("achar-play") o que fazer diretamente no amplo espaço escolhido (o "ground"). As ações seriam, idealmente, feitas ao longo do tempo, in progress, de acordo com os planos e as abordagens dos propositores, sem que houvesse um momento pré-definido para acabar ${ }^{48}$. É somente no dia 18 de dezembro daquele ano, porém, que é realizado, em locais variados do bairro, o que o artista sugeria ser o primeiro de uma série de acontecimentos poético-urbanos no contexto do programa in progress CAJU. Concebido como uma homenagem ao centenário de nascimento do artista suíço Paul Klee (1879-1940), assumidamente uma das maiores influências de Hélio Oiticica, o acontecimento foi nomeado de Kleemania, para o qual o artista contribuiu com a primeira versão do trabalho Devolver a Terra à Terra $(1979)^{49}$. Nessa ação, coletou terra escura de uma parte distinta da cidade - Jacarepaguá - e a transportou até o aterro de lixo do bairro do Caju, despejando a matéria recolhida sobre a terra daquele lugar no espaço delimitado por uma forma vazada de madeira posta sobre o chão, que foi depois dali retirada ${ }^{50}$.

Se era explícito que a concepção do programa in progress CAJU se ancorava no conceito e na experiência do delirium ambulatorium, era também claro para o artista o fato de que a tomada do Caju como plataforma de invenção era apenas uma demonstração de algo que poderia ser estendido a toda a cidade do Rio de Janeiro, podendo acontecer, além disso, a qualquer momento:

"o meu approach ao CAJU se deu pelas vias do delirium ambulatorium recuperador-regenerante (como de resto toda a penetração nas diversas áreas da cidade do RIO):

O RIO é

a cidade ideal que amalgama níveis / bairros / regiões totalmente diversas num campo urbano só: o RIO é o paraíso do delirium ambulatorium!" 51

Não por acaso, o segundo acontecimento poético-urbano, proposto para acontecer no dia 9 de fevereiro de 1980 - pouco menos de um par de 
meses após o primeiro -, não ocorre no Caju, mas é planejado para o mor-

ano 10

n 20

52. OITICICA, Hélio.

Esquenta pro carnaval! In: OITICICA FILHO, César (Org.). Op. cit., p. 185-186.

53. A última entrevista. Por Jorge Guinle Filho. Interview, abril de 1980. In: OITICICA FILHO, César;

COHN, Sérgio; VIEIRA, Ingrid (Org.). Op. cit., p. 274.

54. Depoimento de Hélio Oiticica para Ivan Cardoso, janeiro de 1979. In: OITICICA FILHO, César; COHN, Sérgio; VIEIRA, Ingrid (Org.). Op. cit., p. 227.

55. OITICICA, Hélio. Ondas do corpo. In: OITICICA FILHO, César (Org.). Op. cit., p. 174. ro da Mangueira, tendo como ponto de referência o boteco Buraco Quente e concebido como um "esquenta pro carnaval (...) sem hora certa para chegar ou sair" dos convidados. De modo similar ao que fez no primeiro acontecimento poético-urbano, a ideia de Hélio Oiticica era, entretanto, a de criar um "ambiente" - aberto e contíguo ao espaço urbano - propício à emergência de um "estado de invenção" em quem lá esteja e que se deixe afetar pelo acontecimento, provocando o surgimento "aleatório de experiências poéticas programadas ou não". O seu esquenta pro carnaval

"seria um tipo de meditação-ação não introspectiva para o CARNAVAL: meditação não-meditação: ação poética livre: INVENÇÃO

INVENTAR UM PARALELO POÉTICO AO CARNAVAL:

e por

que

não?" 52

Como sua contribuição para o acontecimento, Hélio Oiticica propunha levar um pedaço de madeira ladrilhado para improvisar algumas ações em cima dele, incluindo a construção de maquetes, além de fazer roupa com tecido preto transparente para vestir em si mesmo e em outros, inspirada na camisa de alguém que havia visto em uma das suas novamente frequentes incursões à Mangueira ${ }^{53}$.

Essa segunda proposta para o esquenta pro carnaval se assemelha a algo sugerido pelo artista para compor sua participação em Mitos vadios (item $b$ do texto-release feito para o evento), mas que, tal como a coleta dos fragmentos-tokens, também não foi realizada naquela situação. Reforça, ademais, o lugar importante que a indumentária, e a fantasia em particular, ocupa em seu programa criativo, por seu poder de ressignificar o corpo. Em certa ocasião, Hélio Oiticica chegou a aproximar, conceitualmente, as capas de Parangolé àquelas fantasias que, sem pretender representar personagens estáveis, são "invenção gratuita e improvisação trivial”, dessa maneira contrapondo-se ao preconceito, comum ao meio crítico da época, em relação ao embate do corpo com o mundo como forma de conhecimento irredutível à razão ${ }^{54}$. Como o artista resumiu, "o VESTIR improvisado torna-se elemento estrutural para a descoberta do corpo" ${ }^{5}$. E, ao observar as fotografias que registram a sua participação em $\mathrm{Mi}$ tos vadios, é possível perceber, nas roupas e acessórios usados, essa vontade de 
inventar algo novo por meio do ajuntamento, no próprio corpo, de referências

MOACIR DOS ANJOS

As ruas e as bobagens:

anotações sobre o

delirium ambulatorium

de Hélio Oiticica

56. OITICICA, Hélio.

Texto-legenda de foto para o suprassensorial, enviado para Revista

Artes. Documento 1597/ sd, acervo Projeto Hélio Oiticica.

57. OITICICA, Hélio.

Anotações sobre o parangolé. In: OITICICA FILHO, César (Org.). Op. cit., p. 83.

58. Depoimento de Hélio Oiticica para Ivan Cardoso, janeiro de 1979. In: OITICICA FILHO, César; COHN, Sérgio; VIEIRA, Ingrid (Org.). Op. cit., p. 241.

59. OITICICA, Hélio. O q faço é música. In: OITICICA FILHO, César (Org.). Op. cit., p. 179-180. 
ARS sica e a dança possuem para que se entre em um "estado de invenção" 58 . ano 10 Não é por acaso, afinal, que afirmou que o que fazia era "MÚSICA e n 20 que MÚSICA não é 'uma das artes' mas a síntese da consequência da descoberta do corpo" 59 .

Por sua natureza fugidia, o delirium ambulatorium não possui, na obra de Hélio Oiticica, o estatuto de outras de suas criações, tais como os Núcleos, os Penetráveis, os Bólides e os Parangolés. Mesmo ambientes complexos e resistentes a explicações como Tropicália e Éden são mais bem delineados e reconhecidos como trabalhos quando comparados à posição, por ele esposada, de tomar o ato de deambular pela cidade como

60. OITICICA, Hélio. Anotações sobre o parangolé. In: OITICICA FILHO, César (Org.). Op. cit., p. 84-85.

61. CERTEAU, Michel de. Op. cit., p. 183.

62. Idem, Ibidem.

Bólide apropriação, 1978. Foto: César Oiticica Filho. estopim da "invenção". O delirium ambulatorium talvez seja, porém, a expressão mais radical do Parangolé, entendido este em seu sentido amplo: como programa ambiental que busca quebrar as distinções entre ateliê e rua e, principalmente, entre artista e público, acionando o segundo como "participante na atividade criadora" e instaurando uma forma de expressão genuinamente disseminada e coletiva ${ }^{60}$.

É no transitar na cidade, e não mais no interior do ateliê ou mesmo da casa ou de algum abrigo, que o artista melhor percebe as coisas vagas e imprecisas que informam ações a desenvolver. Afinal, caminhar, como diz Michel de Certeau, "é ter falta de lugar", é busca do que está ainda a ser inventado ${ }^{61}$. É nessa atividade ordinária que Hélio Oiticica diz intuir movimentos e ter "vislumbres", associando o delirium ambulatorium a uma meditação "conduzida pelo pé"62. Em veio semelhante, mas em outro contexto, sugere a ligação dessa prática a uma "hora do sonho", expressão usada por aborígenes australianos para descrever os momentos em que abandonam as suas casas e vagueiam sozinhos sem saber para onde ${ }^{63}$. E se
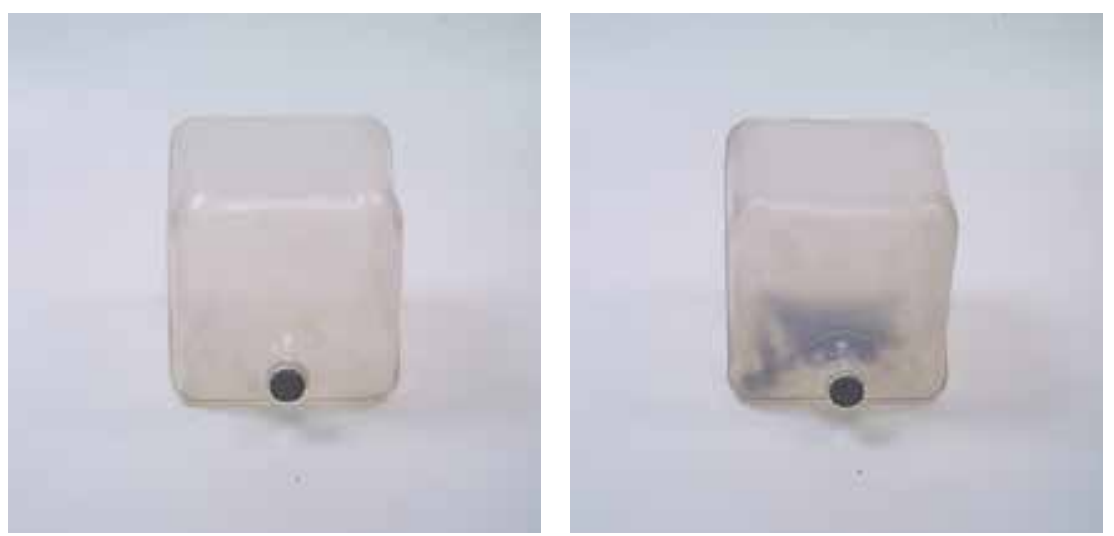
sonho é estado inconsciente em que tudo pode ser concebido, o delirium ambulatorium pode ser similarmente associado a um estado de vigília, aquele em que, entre o despertar e o sono, as coisas perdem contorno certo e podem aludir ao que antes não se sabia. O destaque que Hélio Oiticica crescentemente dá a essa ideia após o seu retorno ao Brasil, em 1978, parece amparar, por fim, uma vontade de estender, a toda a cidade do Rio de Janeiro, a sua intensa vivência (agora desmitificada) na Mangueira, único lugar onde dizia não ter vislumbres, pelo mero fato de tudo lá já o $\operatorname{ser}^{64}$. Destaque que exprime o desejo de transformar o Rio de Janeiro em "labirinto topográfico da paixão delirium ambulatorial"65.

É preciso notar, entretanto, que apontar a andança ociosa como expressão radical do Parangolé - entendido como projeto de ambientação do corpo no mundo - implica igualmente admitir que o delirium ambulatorium coloca o Programa de Hélio Oiticica, no qual o próprio deambular obviamente se inscreve, em uma situação-limite. A consciência desse paradoxo está expressa, de maneira clara, em um texto preparatório para o programa in progress CAJU:

“(...) pelo delirium ambulatorium não só saio da quase-imobilidade do 'workshop-fermento' como dou consequência às aspirações ali nascidas: se não só consequência - mais - meditação delas (dar consequências; dos projetos fermentados; dos pequenos vislumbres do 'que quero fazer'):

pelo delirium

ambulatorium o campo urbano / o campo visual-ambiental / o campo humano são approached de um modo totalmente free (mais per-

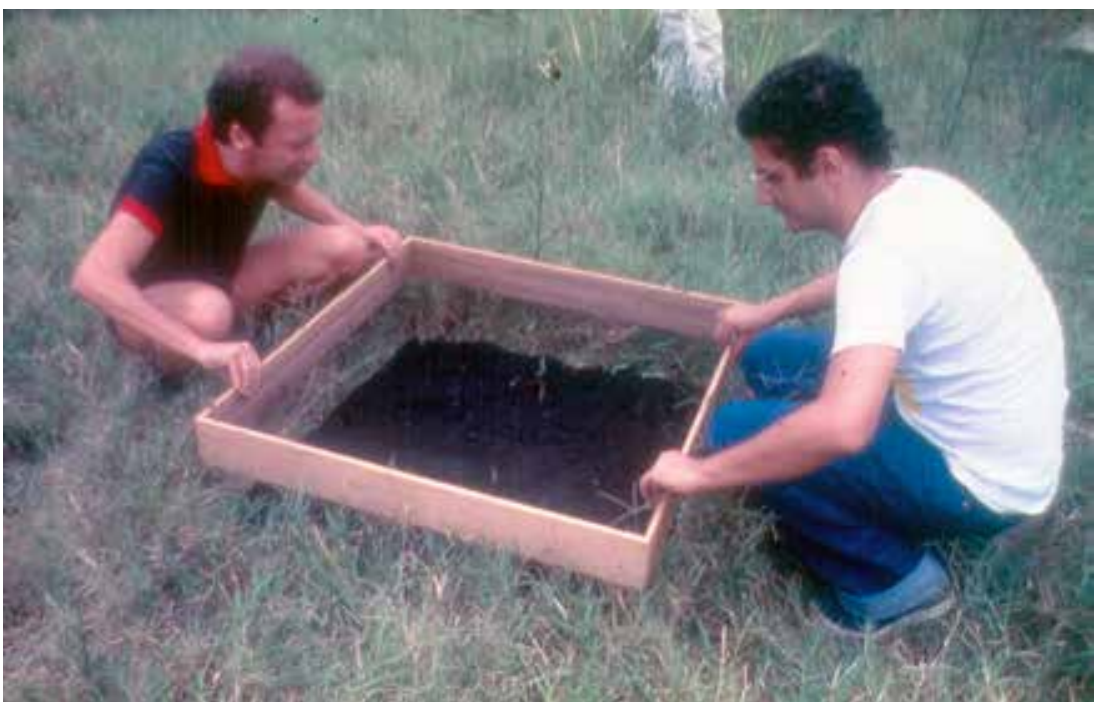

MOACIR DOS ANJOS

As ruas e as bobagens: anotações sobre o delirium ambulatorium de Hélio Oiticica

63. Entrevista a Guy Brett. Londres, fevereiro de 1969. In: OITICICA FILHO, César; COHN, Sérgio; VIEIRA, Ingrid (Org.). Op. cit., p. 61.

64. Depoimento de Hélio Oiticica para Ivan Cardoso, janeiro de 1979. In: OITICICA FILHO, César; COHN, Sérgio; VIEIRA, Ingrid (Org.). Op. cit., p. 239.

65. OITICICA, Hélio. Manifesto Caju, manuscrito datado de 11.04 a 7.10 de 1979, p. 5. Manuscrito, documento 0114/79, acervo Projeto Hélio Oiticica.

Contra Bólide No 1 Devolver a Terra à Terra, 1979, realizado no Aterro do Caju, Rio de Janeiro, durante o evento Kleemania. Foto: Andreas Valentin. 
ARS

ano 10

n 20

66. Idem, Ibidem, p. 3-4.

67. Nesse sentido, 0 delirium ambulatorium confrontaria, como resultado da lógica interna e paradoxal do Programa de Hélio Oiticica - e não como resultado anômalo de seu desdobrar ao longo do tempo -, a crítica, frequentemente posta, de que, ao buscar borrar arte e vida, o artista terminava por construir ambientes ainda mais "preservados do contágio do mundo". Para a formulação dessa crítica, ver RAMOS, Nuno. À espera de um sol

Contra Bólide N²- “A tua na minha", 1979, realizado no evento coletivo

"Esquenta pro Carnaval", realizado na Escola de Samba de Mangueira. Foto: Andres Valentin.

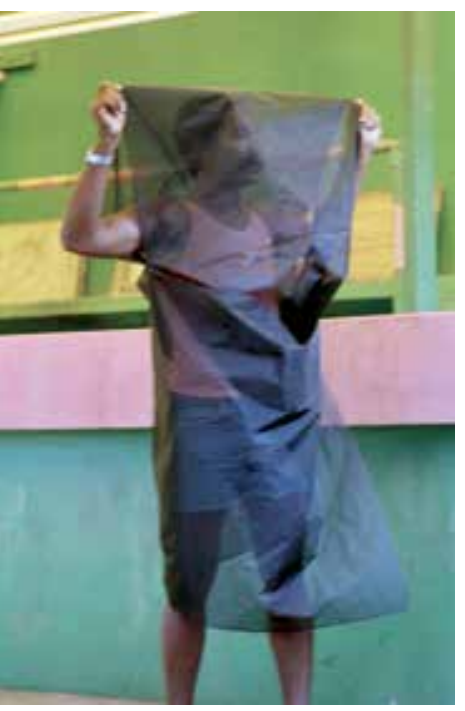

to das transformações criativas do que antes) como também sem compromisso: sem consequência:

É A

BUSCA DA FALTA DE

CONSEQUENCIA:

É O NÃO-

PROGRAMA!”66

Por ser um estar no mundo, um jogar-se na vadiagem, o delirium ambulatorium é a extensão radical do Suprassensorial e do Crelazer, é o abrir-se para o que está nas ruas em busca de elementos - prosaicos ou extraordinários, suaves ou ásperos - que permitam a recriação constante de subjetividades, conduzindo a um estado de invenção que gradualmente tome mais espaço da vida de cada um. É habitar um Barracão sem janelas ou portas, confundido, em sua indefinida extensão, com a própria cidade. Ou percorrer uma Magic Square que, em desmedido processo de hibridação, borra seus limites e se integra a outras muitas paredes e passagens que dão forma ao traçado urbano ${ }^{67}$. Como o artista escreve na parte final do texto-release feito para o evento Mitos vadios,

"AS RUAS E AS BOBAGENS DO NOSSO DAYDREAM DIÁRIO SE ENRIQUECEM

VÊ-SE QUE ELAS NÃO SÃO BOBAGENS NEM TROUVAILLES SEM CONSEQUÊNCIA

SÃO O PÉ CALÇADO PRONTO PARA O DELIRIUM AMBULATORIUM

RENOVADO A CADA DIA" ${ }^{68}$.

O delirium ambulatorium é, portanto, uma proposta de emancipação do corpo. Emancipação que não é mais assistida por objetos e situações criados ou propostos pelo artista (seja com Núcleos, Bólides, Penetráveis, capas ou mesmo com ambientes), mas antes deflagrada pelo embate direto e imediato com o mundo. É algo já intuído e implicado no próprio conceito de Parangolé, por meio do qual Hélio Oiticica propunha estender o sentido de apropriação às coisas com que se depara "nas ruas, terrenos baldios, campos, o mundo ambiente, enfim - coisas que não seriam transportáveis, mas para as quais eu chamaria o público à participação"69. $\mathrm{O}$ paradoxo, do ponto de vista do Programa do artista, é que implícita nesse 
chamado radical à participação no "mundo ambiente" por meio do delirium ambulatorium está também a sua despersonalização. Hélio Oiticica sai gradualmente de cena e torna-se propositor somente de uma ideia de participação. Não há mais trabalho algum a ser visto, tampouco há sentido para a ideia de espectador, mesmo nos moldes do participador dos ambientes feitos em recintos fechados ou dos acontecimentos poéticos urbanos. O museu transforma-se efetivamente no mundo, na "experiência cotidiana”, e o “verdadeiro 'fazer' seria a vivência do indivíduo"70. Por ter morrido tão cedo, não é possível saber ao certo o que Hélio Oiticica poderia ainda propor a partir daí, embora seja tentador sugerir, amparado no estado a que chegou sua investigação artística, que tenha concluído seu Programa, dissolvendo-o nas ruas.
MOACIR DOS ANJOS

As ruas e as bobagens: anotações sobre o delirium ambulatorium de Hélio Oiticica

interno. In: Ensaio geral: projetos, roteiros, ensaios, memórias. São Paulo: Editora Globo, 2007. p. 121-123. Apud WISNIK, Guilherme. Public Space on the Run. Brazilian Art and Arcitecture at the End of the 1960s. Third Text, v. 26, n. 1, p. 117-129, jan. 2012.

68. OITICICA, Hélio. Mitos vadios. In: OITICICA FILHO, César (Org.). Op. cit., p. 178.

69. OITICICA, Hélio. Anotações sobre o parangolé. In: OITICICA FILHO, César (Org.). Op. cit., p. 82.

70. OITICICA, Hélio. 0 aparecimento do suprassensorial na arte brasileira. In: OITICICA FILHO, César (Org.). Op. cit., p. 106.

Hélio Oiticica no evento “Mitos Vadios”. São Paulo,

1978. Foto: Solón Ribeiro.
Moacir dos Anjos é pesquisador e curador de artes visuais da Fundação Joaquim Nabuco. Foi diretor do Museu de Arte Moderna Aloísio Magalhães - MAMAM (Recife) de 2001 a 2006, e pesquisador visitante no Research Centre for Transnational Art, Identity and Nation - TRAIN, University of the Arts (Londres), entre 2008 e 2009. Curador do Pavilhão Brasileiro da 54ª Bienal de Veneza (2011), da 29a Bienal de São Paulo (2010), co-curador da 6a Bienal do Mercosul (Porto Alegre, 2007) e curador do $30^{\circ}$ Panorama da Arte Brasileira, no MAMSP (2007), é autor, entre outros, dos livros Local/Global - Arte em Trânsito (Rio de Janeiro, Zahar, 2005) e ArteBra Crítica - Moacir dos Anjos (Rio de Janeiro, Automática, 2010). 


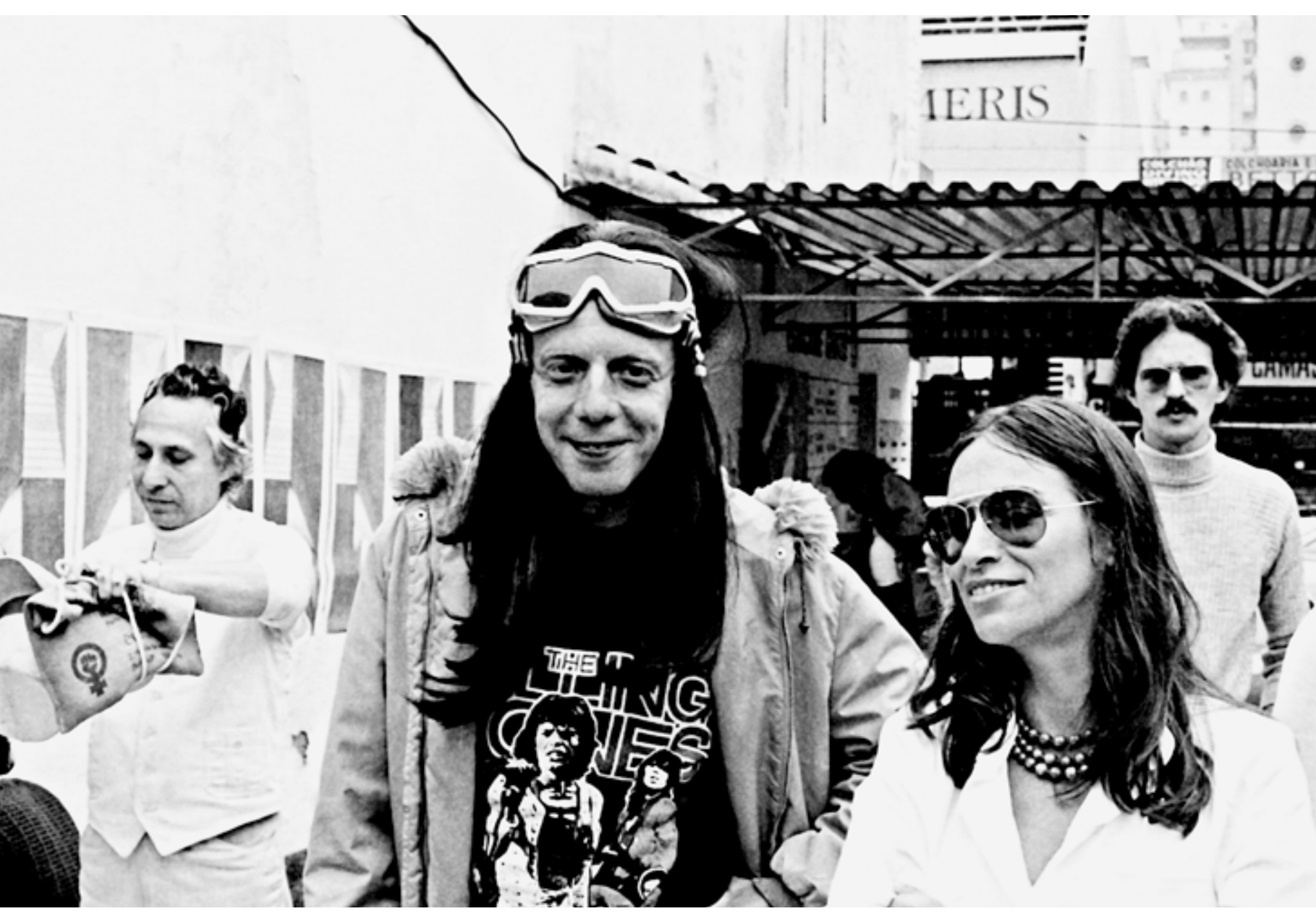

